\title{
Effect of cigarette smoke on bronchial reactivity
}

\author{
JL WRIGHT MD, J-P SUN MD, S VEDAL MD, A CHURG MD \\ Departments of Pathology and Medicine, University of British Columbia, \\ Vancouver, British Columbia
}

JL Wright, J-P Sun, S VEdal, A Churg. Effect of cigarette smoke on bronchial reactivity. Can Respir J $1995 ; 2(4): 231-235$.

OBJective: To compare the effects of a bricf low level exposure to cigarette smoke in rats with known low (Sprague-Dawley) and high (Fisher) airway responsiveness, to test the hypothesis that airways reactivity influences the severity or duration of pulmonary function alterations after cigarette smoke exposure.

METHODS: Baseline pulmonary function tests and methacholine dose response tests were conducted in 10 SpragueDawley and 10 Fisher rats. On the following day, the animals were reanaesthetized, and breathed for $1 \mathrm{~min}$ from a $2 \mathrm{~L}$ chamber into which $25 \mathrm{~mL}$ of fresh cigarette smoke had been injected, followed by a second set of pulmonary function and methacholine response tests; a final set was performed two weeks later.

RESULTS: Sprague-Dawley rats were larger, with larger lung volumes, compliance and flow rates, but Fisher rats showed a fourfold higher airway reactivity. Although nei- ther resistance nor response to methacholine changed in either strain of animal, Sprague-Dawley rats showed an increase in residual volume post smoke, which was not sustained over two weeks, and sustained small increases in vital capacity, total lung capacity and static lung compliance, with a sustained decrease in forced expiratory volume in $0.1 \mathrm{~s}$, while Fisher rats showed only a small sustained increase in functional residual capacity.

CONCLUSIONS: Although there are marked differences in pulmonary function between the two different strains of rats, increased airways responsiveness per se does not make the animal more sensitive to the acute effects of cigarcte smoke, and the effects of cigarette smoke on pulmonary function are not necessarily related to increased airway resistance. Pulmonary function alterations seen after brief cigarette smoke exposure may be sustained for a relatively long period of time. (Pour le résumé, voir page 232)

Key Words: Airways responsiveness. Cigarette smoke. Putmonury function 


\section{Effet de la fumée de cigarette sur la réactivité bronchique}

OBJECTIF : Comparer les effets d'un faible et bref niveau d'exposition à la funcée de cigarette chez des rats Sprague-Dawley connus pour avoir une faible réactivité bronchique et des rats Fisher ayant une forte réactivité bronchique : vérifier si la réactivité bronchique influence la gravité ou la durée des atteintes de la fonction pulmonaire après une exposition à la fumée de cigarette. MÉTHODEs : Des épreuves de fonction respiratoire de base el des tests de provocation bronchique à la méthacholine ont été menés chez 10 rats Sprague-Dawley et 10 rats Fisher. Le jour suivant, les animaux ont été réanesthésiés, ct ont respiré pendant unc minute de l'air provenant d'une chambre de $2 \mathrm{~L}$ dans laquelle $25 \mathrm{~mL}$ de fumée de cigarette avaient été fraîchement injectés. Ensuite, on a procédé à une deuxième épreuve de fonction respiratoire el à un second test de provocation bronchique à la méthacholine. Une série finale de tests a été pratiquée deux semaines plus tard.

RESLLTATS : Les rats Sprague-Dawley étaient plus gros, avec des volumes pulmonaires, une compliance et des débits plus grands.
Cependant, les rats Fisher ont démontré une réactivité bronchique 4 fois supérieure à celle des rats Sprague-Dawley. La résistance ou la réponse à la méthacholine sont restées les mêmes chez les deux races de rats; cependant, les rats Sprague-Dawley présentaient une augmentation du volume résiducl suite à leur exposition à la fumée qui ne subsistait plus après deux semaines. Ils présentaient également de faibles augmentations soutenues de la capacité vitale, de lit capacité pulmonaire totale et de la compliance pulmonaire statique ainsi qu'une diminution soutenue du volume expiratoire maximum/seconde. Les rats Fisher présentaient uniquement une petite augmentation soutenue de la capacité résiduelle fonctionnelle.

Conclustons : Bien qu'il y ait des différences appréciables de la fonction respiratoire entre les deux races de rats, l'augmentation de la réactivité bronchique per se ne signifie pas que l'animal est plus sensible aux effets aigus de la fumée de cigarette, et les effets de la fumée de cigarette sur la fonction respiratoire ne sont pas nécessairement liés à l'augmentation de la résistance des voies aériennes. Les altérations de la fonction respiratoire observées après une brève exposition à la fumée de cigarette peuvent durer pendant une période relativement longue.
B RONCHLAL HYPERREACTIVITY MAY BE AN IMPORTANT determinant of disease susceptibility in chronic obstructive pulmonary disease (COPD) $(1,2)$. I ongitudinal studies have indicated that airwatys hyperreactivity (3) and lack of response to bronchodilators $(3,4)$ are important predictors of an increased rate of decline in forced expiratory volume in $1 \mathrm{~s}$ $\left(F E V_{1}\right)$, independent of the effects of smoking. Similarly, a recent study of young cigarette smokers (5) has shown that 1 1c presence of wheezing, probably indicative of lung hyperresponsiveness, is predictive of a progressive loss of ventilitory function. A recent multicentre clinical trial (Lung Health Study) showed that current smokers with functional evidence of early COPD had nonspecific airways hyperresponsiveness that was related to the baseline values for lung function (6). Tashkin and colleagues (7) have recently shown a dose-dependent effect of tobacco smoking with airways responsiveness, which appears to be independent of the effects of lung function. This latter study would support the concept that cigarette smoke has a primary effect on airways hyperresponsiveness.

Passive smoke exposure has also been related to increased airways responsiveness, both in children at home (8) and in adults at their workplace (9). Mechanisms of induction of airway reactivity in these studies are unclear, but it has been suggested that the process may be related to an inflammatory response in the airways. Although, in many animals, an acute exposure to cigarette smoke may be associated with an immediate increase in airways resistance ( $10-13$ ) and appears to make the airways more sensitive to standard doses of acetylcholine (14) or methacholine (13.15), the mechanism is dispultecl.

In the present study, we wisled to ascertain whetler imalle airways hyperreactivity would cause animals to halve a greater sensitivity to a brief low level exposure to cigarette smoke, and thus result in sustained increases in airways resistance or methacholine responsiveness. To test this liypothe- sis, two groups of rats with different degrees of airways responsiveness were selected. We chose the Fisher rat for one group since this strain is known for its sensitivity to standard bronchoconstrictive agents (16), and it is also known that these animals have significantly more airway wall smooth muscle than is found in a less responsive strain of rat (16). SpragueDawley rats were chosen as a normoresponsive control.

\section{ANIMALS AND METHODS}

(iroups of 10 Sprague-Dawley and 10 Fisher rats were used. On day 1, baseline pulmonary function tests and methacholine challenge were performed as documented below: on day 2, the animals were re-anaesthetized and were allowed to breathe for $1 \mathrm{~min}$ from a $2 \mathrm{~L}$ chamber containing $25 \mathrm{~mL}$ fresh cigarette smoke. This dose was chosen from an initial study using Sprague-Dawley rats that demonstrated that this smoke concentration would produce an initial rise in airways resistance that would not be sustained after 10 mins. Ten minutes after the smoke inhalation, repeat pulmonary function tests and methacholine challenge were done. A final s.t of pulmonary function tests and methacholine challenge were performed two weeks after initial baseline values. To determine that methacholine responsiveness did not change due to the experimental procedure, a control group of five Sprague-Dawley rats was studied using the same protocol.

Pulmonary function tests were performed as follows: the rats were anaesthetized with a combination of intraperitoneal diazepam ( $5 \mathrm{mg} / \mathrm{kg}$ ) and intramuscular fentanyl droperidol (Janssen Pharmaceutical) $(0.2 \mathrm{mg} / \mathrm{kg}$ ). After intubation with a 14-gauge intravenous cannula using a pediatric laryngoscope and a tilted table, the rats were placed in a pressure sensitive $7.5 \mathrm{~L}$ small animal plethysmograph and ventilated at 80 breaths $/ \mathrm{min}$ at a tidal volume of approximatcly $2 \mathrm{~mL}$. A water filled esophageal tube (size PE 240, Intramedic catheter. Clay Adams, New Jersey) with a multiholed tip was used 10 measure pleural pressure; transpulmonary pressure was 
TABLE 1

Baseline values and pulmonary function results for Sprague-Dawley and Fisher rats

\begin{tabular}{|c|c|c|c|c|c|c|}
\hline \multirow{2}{*}{$\begin{array}{l}\text { Pulmonary } \\
\text { function }\end{array}$} & \multicolumn{3}{|c|}{ Sprague-Dawley rats } & \multicolumn{3}{|c|}{ Fisher rats } \\
\hline & BL & $\mathbf{s}$ & PS & BL & $\mathrm{s}$ & PS \\
\hline $\mathrm{RV}(\mathrm{mL})$ & $4.1 \pm 1.7$ & $5.8 \pm 1.4^{*}$ & $5.5 \pm 1.9$ & $4.3 \pm 1.5$ & $4.7 \pm 1.4$ & $4.3 \pm 1.5$ \\
\hline FRC $(\mathrm{mL})$ & $9.0 \pm 0.5$ & $9.3 \pm 0.7$ & $9.0 \pm 0.5$ & $7.3 \pm 0.2^{\dagger}$ & $8.2 \pm 0.2^{*}$ & $7.5 \pm 0.2^{*}$ \\
\hline$V C(m L)$ & $19.4 \pm 1.3$ & $20.2 \pm 1.5^{*}$ & $20.9 \pm 1.8^{*}$ & $12.5 \pm 1.1^{\dagger}$ & $13 \pm 0.9$ & $12.8 \pm 1.6$ \\
\hline $\mathrm{TLC}(\mathrm{mL})$ & $23.4 \pm 2.1$ & $26 \pm 1.8^{*}$ & $26.4 \pm 1.3^{*}$ & $16.8 \pm 1.3^{\dagger}$ & $17.6 \pm 1.1$ & $17.1 \pm 1.8$ \\
\hline $\mathrm{Cst}\left(\mathrm{mL} / \mathrm{cm} \mathrm{H} \mathrm{H}_{2} \mathrm{O}\right)$ & $0.78+0.27$ & $1.01+0.3^{*}$ & $1.04 \pm 0.29^{*}$ & $0.54 \pm 0.18^{\dagger}$ & $0.44 \pm 0.21$ & $0.54 \pm 0.28$ \\
\hline $\mathrm{FEV}_{0.1}(\mathrm{~mL})$ & $5.2 \pm 1.1$ & $4.1 \pm 1.1^{*}$ & $3.3 \pm 1.0^{*}$ & $4.5 \pm 0.8$ & $4.1+0.9$ & $2.7 \pm 1.1$ \\
\hline $\mathrm{FEF}_{25-75}(\mathrm{~mL} / \mathrm{s})$ & $86+37$ & $108 \pm 21$ & $107 \pm 9$ & $77 \pm 13$ & $79 \pm 18$ & $82 \pm 12$ \\
\hline $\mathrm{PEF}(\mathrm{mL} / \mathrm{s})$ & $140 \pm 15$ & $144 \pm 17$ & $149 \pm 15$ & $106 \pm 10^{\dagger}$ & $107 \pm 16$ & $105 \pm 12$ \\
\hline
\end{tabular}

'Significantly different from baseline values. ${ }^{\dagger}$ Significantly different from Sprague-Dawley rats' baseline values. BL Baseline; Cst Static lung compliance; FEF Forced expiratory flow between 25 and $75 \%$ forced vital capacity; FEV 0.1 Forced expiratory volume in 0.1 s; FRC Functional residual capacity: PEF Peak expiratory flow; PS Two weeks post smoke; R200 Methacholine dose that doubles the baseline resistance; RES Dynamic airways resistance; RV Residual volume; $S 10$ mins after smoke exposure; TLC Total lung capacity: VC Vital capacity

calculated as the difference between mouth and pleural pressure. Results were analyzed using the RAYTEC computergenerated pulmonary function analysis system (Fine Science Tools). Functional residuil capacity (FRC) was measured by airway occlusion at end-expiration, following which the rats were given supplementiry doses of fentanyl droperidol and were rendered apneic by hyperventilation. Pressure volume curves were constructed from values obtained by deflation to $-30 \mathrm{~cm} \mathrm{H}_{2} \mathrm{O}$, inflation to $+30 \mathrm{~cm} \mathrm{H}_{2} \mathrm{O}$ and deflation to -30 $\mathrm{cm} \mathrm{H}_{2} \mathrm{O}$. Two such inflation-deflation manoeuvres were performed before measurement of the curve (with concurrent calculation of lung volumes expiratory reserve volume, residual volume, vital capacity and total lung capacity [TLC]). Static lung compliance was calculated between FRC and FRC plus $10 \mathrm{~cm}$ transpulmonary pressure. A flow volume curve was constructed from values at inflation to $+30 \mathrm{~cm}$ $\mathrm{H}_{2} \mathrm{O}$ and at rapid deflation at $-50 \mathrm{~cm} \mathrm{H}_{2} \mathrm{O}$ pressure. From this curve, forced vital capacity, forced expiratory flow, forced expiratory flow between 25 and $75 \%$ forced vital capacity (FEF 25-75), FEV 0.1 and peak expiratory flow were calculated. The flow volume curve was plotted by determining the flow it each of the volumes between 30 and 95\% TLC.

The methacholine challenge was performed on spontaneous breathing rats, using a methodology adapted from Martin and colleagues $(17,18)$. An Acorn nebulizer (Trudell Medical) was used with $7 \mathrm{~L} / \mathrm{min}$ air flow, which delivered the particles into a $1 \mathrm{~L}$ vented breathing chamber attached to the endotracheal tube. The rat was allowed to breathe spontaneously from this chamber for 2 mins, and after a $30 \mathrm{~s}$ period of room air breathing, resistance was measured and averaged over approximately 10 breaths. Baseline resistance was measured after delivery of normal saline; then doubling methacholine concentrations from 0.05 to $0.8 \mathrm{mg} / \mathrm{mL}$ were used, followed by concentrations incrementing by 0.25 $\mathrm{mg} / \mathrm{mL}$ from 1 to $5 \mathrm{mg} / \mathrm{mL}$. R200 was calculated from the dose response curve as the concentration of methacholine required to double baseline resistance.

Following the pulmonary function tests, the animals were kept warm, allowed to recover from the anaesthesia and were extubated. They were housed in a laminar hood in standard rat cages with paper pellets as bedding, and were allowed free access to rat chow and water.

The data were first normalized by log transformation. All analyses were done with the SYSTAT system (SYSTAT Inc, Illinois). Unpaired $t$ tests were used to test for strain differences at each point in time. Paired $t$ tests were performed to ascertain whether a change from baseline had occurred within an animal group. Two-way repeated measures analy. sis of variance was used to compare level of pulmonary function both within and between the two animal strains.

\section{RESULTS}

The control animals had mean \pm SD R200 and airwaly resistance, respectively, of $0.85 \pm 0.30$ and $0.06 \pm 0.02$ at baseline, $0.73 \pm 0.30$ and $0.06 \pm 0.02$ post sham smoke, and $1.16 \pm 0.35$ and $0.05 \pm 0.01$ two weeks post sham smoke. Paired $t$ tests showed no difference between time points.

There was a marked difference between the baseline values of the Sprague-Dawley and Fisher rats (Table 1). Although the rats had similar baseline resistance, the Fisher animals demonstrated an approximately fourfold greater responsiveness to methacholine than the Sprague-Dawley rats $(\mathrm{P}<0.003)$. As shown in Table 1 and Figure 1 , Fisher rats had smaller FRC $(\mathrm{P}<0.001)$, vital capacity $(\mathrm{P}<0.00 \mathrm{I})$ and TLC $(\mathrm{P}<0.001)$, with al downward shift of the pressure volumic curve $(\mathrm{P}<0.001)$ and decreased static lung compliance $(\mathrm{P}<0.01)$. Baseline flow volume curves (Figure 2) had significintly reduced flows at comparable percentage TLC compared with those found in the Sprague-Dawley animals $(\mathrm{P}<0.0(1) 2)$, and peak flows were reduced $(\mathrm{P}<0.0(0) 1)$.

In the Sprague-Dawley rats, smoke produced an increasc in residual volume $(\mathrm{P}<0.0(1)$, which did not persist after two weeks. This was associated with an increase in static lung compliance $(\mathrm{P}<0.03)$, and increases in vital capacity $(\mathrm{P}<0.04)$ and TLC $(\mathrm{P}<0.0(0) 1)$, with an upward shift in the pressure volume curve $(\mathrm{P}<0 .(0)(0)$, all of which persisted over two 


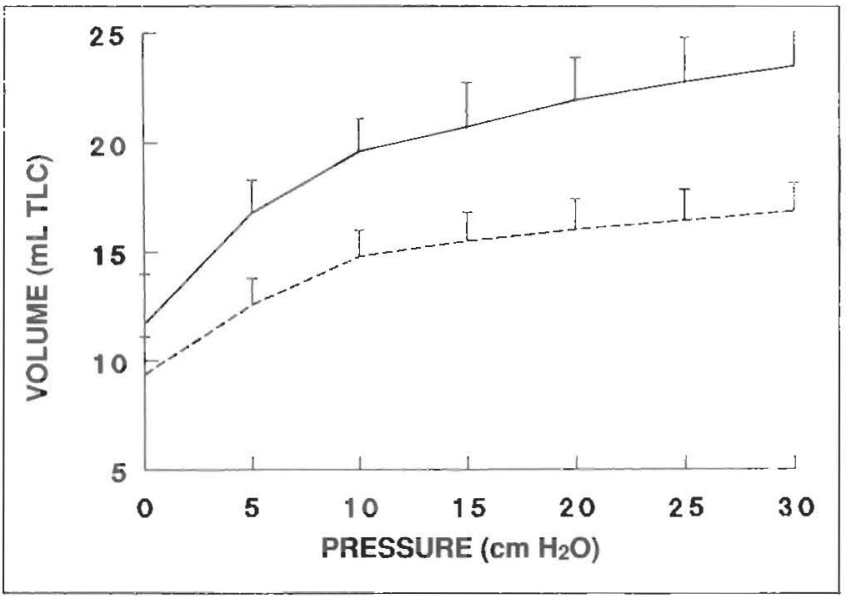

Figure 1) Baseline pressure volume ('urve for Sprague-Dawley (solid line) and Fisher (hatched line) iat strains. Values are mean $\pm S D$ for each group as a whole. There is a significant $(P<0.00 I)$ difference hetween the cures. TLC Tonal lung capacity

wecks $(\mathrm{P}<0.04, \mathrm{P}<0.002, \mathrm{P}<0.005$ and $\mathrm{P}<0.001$, respectively). Although the expiratory flow volume curve was not altered after smoke, the $\mathrm{FEV}_{0.1}$ was significantly diminished $(\mathrm{P}<0.02)$, and there was a further decrease after two weeks $(\mathrm{P}<0.01)$.

In the Fisher rats, the FRC was significantly increased post smoke $(\mathrm{P}<0.001)$, and this change was persistent over the following two weeks $(\mathrm{P}<0.02)$. No other alterations in the lung volumes or pressure volume curve were found; similarly, the flow volume curve and flow rates remained stable.

\section{DISCUSSION}

We devised the present experiments to answer the following questions. First, are there any differences between the acute reactions of a normoreactive (Sprague-Dawley) and a hyperreactive (Fisher) strain of rat to a minimal dose of cigarette smoke? Second, is there any long term effect on the pulmonary function or methacholine reactivity of exposure to a brief, low intensity, dose of cigarette smoke? We found that, regardless of initial airways responsiveness, this minimal exposure did not increase sensitivity to methacholine. It did, however, alter pulmonary function, and several of these alterations were persistent. Surprisingly, the pulmonary function changes were primarily seen in the less responsive Sprague-Dawley animals, with only the FRC being altered in the Fisher rats.

In humans, short term inhalation of sidestream smoke will produce a dose-related increase in symptoms and a significant decrease in pulmonary function in patients with increased methacholine sensitivity (19). Other studies in animals have shown that cigarette smoke will increase airways resistance (11-14). Xu and colleagues (15) exposed rats to three cigarettes per day, five days per week, for 15 weeks. They found that this regimen did not alter baseline resistance, but decreased the R200 and allowed the detection of a resistance plateau in the methacholine dose response curve. Although they were able to demonstrate increases in TLC, they could not relate the changes in responsiveness to alterations

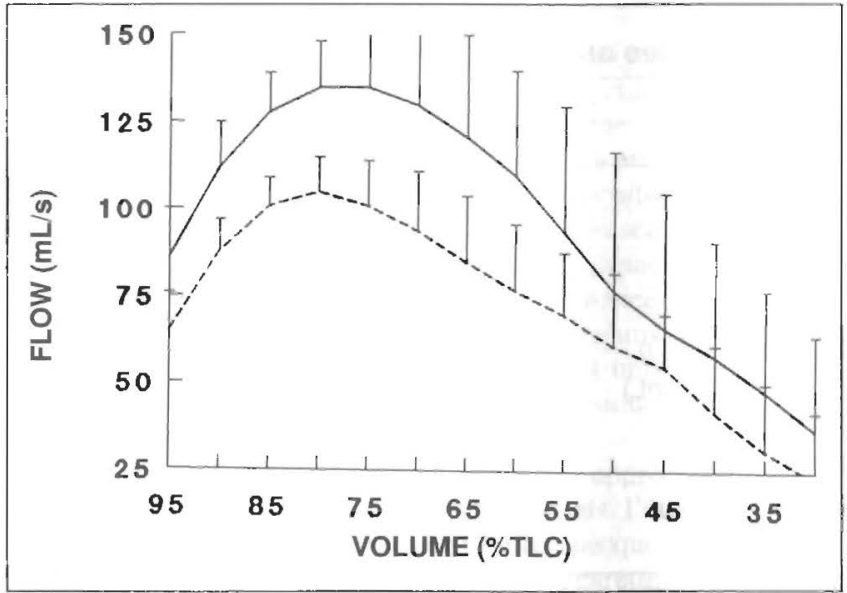

Figure 2) Baseline flow volume curve for Sprague-Dawley (solid line) and Fisher (hatched line) rat strains. Values are mean $\pm S D$ for each group as a whole. There is a significant $(P<0.002)$ difference between the curves. TLC Total lung capacity

of lung elasticity. Our study suggests that changes in lung elasticity, lung volumes and FEV 0.1 may occur very carly in the genesis of cigarette smoke-induced lung disease, predating alterations in airway responsiveness. The nature of the alteration of lung elasticity is unclear; although we have previously found that exposure to cigarette smoke will produce initial destruction of lung collagen matrix (20), the smoke exposure in that study was of much greater intensity and of longer duration than that of the present study.

We do not consider it likely that the changes in pulmoniry function shown in the present study can be attributed to the effects of inflammation. Induction of inflammation by the smoke would preferentially affect the airways and bc reflected in increased resistance or increased bronchial respon. siveness $(10,14)$, changes not found in our study. In support of this conclusion are the studies of $\mathrm{Xu}$ et al (15) and Nishikawa and colleagues (13). Neither of these groups could demonstrate evidence for inflammation after a much more intensive exposure to cigarette smoke.

In humans, airway structure has been suggested to be an important predisposing factor for airways hyperresponsiveness, and may explain the female sex bias for increased airways reactivity in smokers with mild COPD (21). In the present study, we found marked differences in the pulmonary function of Sprague-Dawley and Fisher rats, all lung volumes and flow rates being higher in the former. Some of the differences may be attributable to differences in size as reflected in their weight; Sprague-Dawley animals weighed $475 \pm 39 \mathrm{~g}$ at baseline while the Fisher animals weighed $297 \pm 17 \mathrm{~g}$. The Fisher rats grew only $36 \pm 6 \mathrm{~g}$ compared with $72 \pm 6 \mathrm{~g}$ seen in the Sprague-Dawley animals, suggesting different underlying growth rates. Possible differences in the lung structure in the two strains could also explain the differences in pulmonary function. Eidelman et al (16) showed that the Fisher rats have different airway structure with increased amounts of airway smooth muscle compared with the less responsive Lewis rats, and suggested that they may explain 
the differences in innate airway responsiveness. It is also possible that these differences in lung structure could additionally explain the paucity of cigarette smoke-induced changes in pulmonary function in the Fisher compared with the Sprague-Dawley rats.

\section{CONCLUSIONS}

Although a brief, low intensity dose of cigarette smoke does not alter airways resistance or responsiveness, il does produce alterations in pulmonary function, some of which are

\section{REFERENCES}

1. Orie NGM, Sluiter HJ, DeVries K, Tammeling GJ, Witkop I. The host factor in bronchitis. In: Orie NGM, Sluiter HJ, eds. Bronchitis. Assen: Royal Vangorcum, 1961:43

2. Sluiter HJ, Koeter GH, de Monchy JGR, Postma DS, de Vries $\mathrm{K}$, Orie NGM. The Dutch hypothesis (chronic nonspecific lung disease) revisitcd. Eur Respir J 1991;4:479-89.

3. Postma DS, Sluiter HJ. Prognosis of chronic obstructive pulmonary disease: the Dutch experience. Am Rev Respir Dis 1989; 140:s100-s 105

4. Anthonisen NR. Prognosis in chronic obstructive pulmonary disease: results from multicenter clinical trials. Am Rev Respir Dis 1989; 140:S95-S99.

5. Jalakkola MS, Jaakkola JJK, Ernst P, Becklake MR. Ventilatory lung function in young cigarette smokers: a study of susceptibility. Eur Respir J 1991;4:643-50.

6. Tashkin DP, Altose MD, Bleecker ER, et al. The lung health study: airway responsiveness to inhaled methacholine in smokers with mild to moderate airflow limitation. Am Rev Respir Dis 1992;145:301-10.

7. Tashkin DP, Simmons MS, Chang P, Liu H, Coulson AH. Effects of smoked substance abuse on nonspecific airway hyperresponsiveness. Am Rev Respir Dis 1993;147:97-103.

8. Forastiere F, Agabiti N, Corbo GM, et al. Passive smoking as a determinant of bronchial responsiveness in children. Am J Respir Crit Care Med 1994;149:365-70.

9. Leuenberger P, Schwartz J, Ackermann-Licbrich U, et al. Passive smoking exposure in adults and chronic respiratory sympioms (SAPALDIA study). Am J Respir Crit Care Med 1994;150:1221-8.

10. Hulbert WM, McLean T, Hogg JC. The effect of acute airway inflammation on bronchial reactivity in guinea pigs. Am Rev Respir Dis 1985;132:7-I1.

11. Nakamura M, Haga T, Sasaki H, Takishima T. Acute effects of cigarette smoke inhalation on peripheral airways in dogs. persistent, at least in the short term. The changes are apparently not related to airways responsiveness and are more pronounced in the normoresponsive rats. The increased airways responsiveness that can be produced by exposure to cigarette smoke appears to be separate from other alterations in pulmonary function.

ACKNOWLEDGEMENTS: Supported by grants from the BC Hcalıh Care Research Foundation.

J Appl Physiol 1985;58:27-33.

12. Nakamura M, Hildebrandt J. Cigarette smoke acutely increases collateral resistance in excised dog lobes. J Appl Physiol 1984;56:166-74.

13. Nishikawa M, Ikeda H, Fukada T, Suzuki S, Okubo T. Acutc exposure to cigarette smoke induced airway hyperresponsiveness without airway inflammation in guinea pigs. Am Rev Respir Dis 1990;142:177-83.

14. James AL, Dirks P, Ohtaka H, Schellenberg RR, Hogg JC. Airway responsivensss to intravenous and inhaled acetycloline in the guinea pig after cigarette smoke exposure. Am Rev Respir Dis 1987;136:1158-62.

15. Xu LJ, Dandurand RJ, Lei M, Eidelman DH. Airway hyperresponsiveness in cigarette smoke-exposed rats. Lung 1993;171:95-107.

16. Eidelman D, Dimaria GU, Bellofiore S, Wang N-S, Guttmann RD, Martin JG. Strain-related differences in airway smooth muscle and airway responsiveness in the rat. Am Rev Respir Dis 1991;144:792-6.

17. Renzi PM, Sapienza S, Du T, Wang N-S, Martin JG. Lymphokine-induced airway hyperresponsiveness in the rat. Am Rev Respir Dis 1991;143:375-9.

18. Wang CG, Dimaria G, Bates JHT, Guttmann RD, Martin JG. Methacholine-induced airway reactivity of inbred rats. J Appl Physiol 1986;61:2180-5.

19. Danuser B, Weber A, Hartmann AL, Krueger H. Effects of a bronchoprovocation challenge test with cigarette sidestream smoke on sensitive and healthy adults. Chest 1993; 103:353-8.

20. Wright JL, Churg A. Smoke-induced emphysema in the guinca pig is asociated with morphometric evidence of collagen breakdown and repair. Am J Physiol 1995;268:L17-20.

21. Kanner RE, Connett JE, Altose MD, et al. Gender difference in airway hyperresponsiveness in smokers with mild COPD. Am J Respir Crit Care Med 1994;150:956-61. 


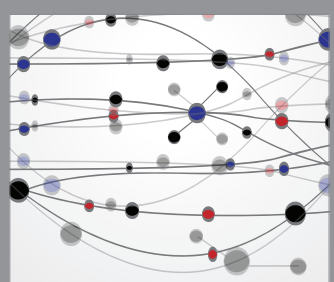

The Scientific World Journal
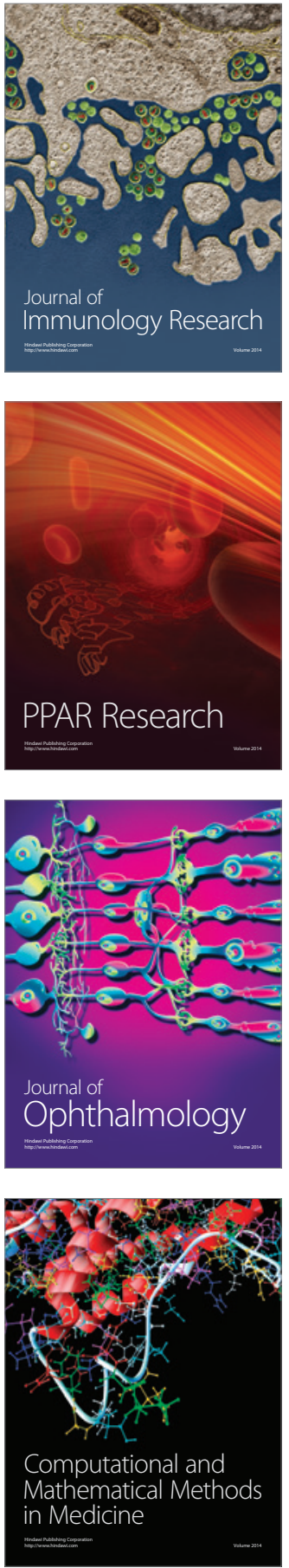

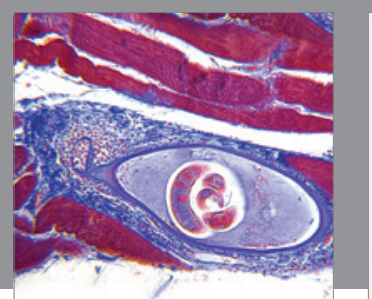

Gastroenterology Research and Practice

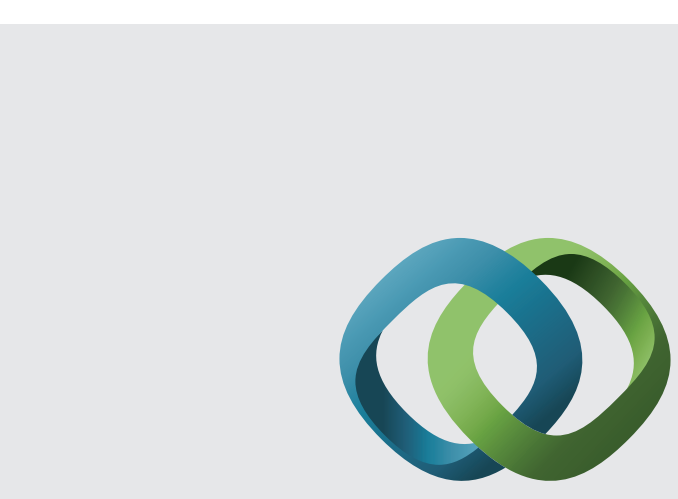

\section{Hindawi}

Submit your manuscripts at

http://www.hindawi.com
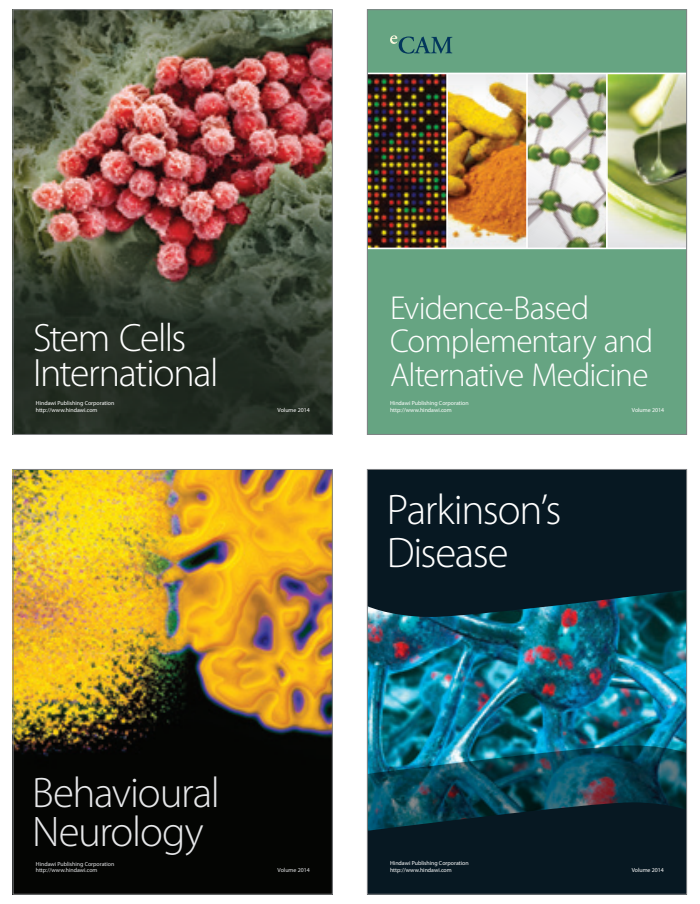
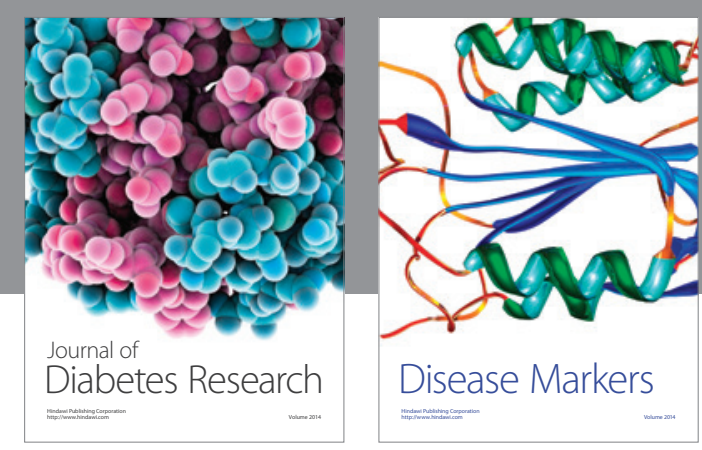

Disease Markers
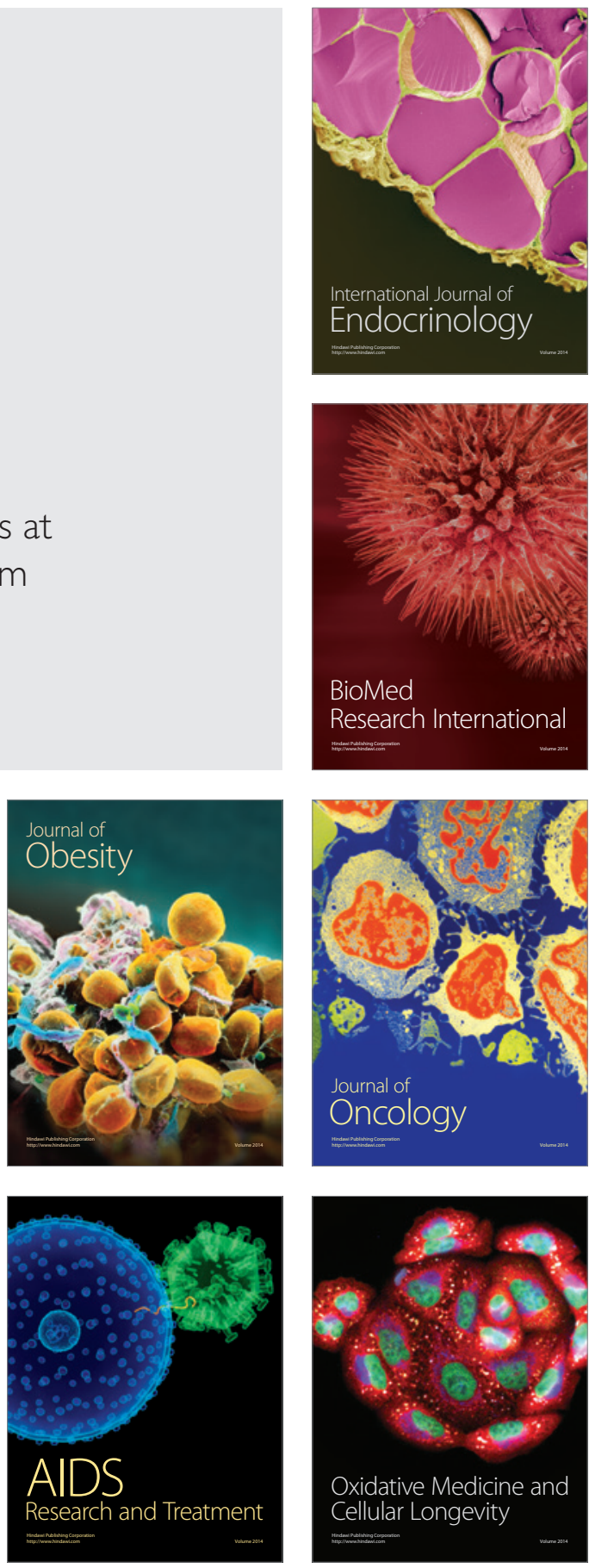